\title{
Contributions of Humanitarian agencies among refugees and host communities in Handeni District, Tanzania
}

\author{
Dr. Nelson Jagero (Corresponding author) \\ Senior Lecturer, School of Post Graduate Studies, Kampala International University \\ Dar-es-Salaam College, P.O. Box 9790 \\ Dar es Salaam, Tanzania \\ Email: jagero66@gmail.com
}

Timothy Asasira

Kampala International University (K I U), Tanzania

E-mail: timoasa@gmail.com

Received: September 20, 2011 Accepted: December 18, 2011 DOI: 10.5296/jpag.v2i1.1266

\begin{abstract}
This study focused on the Contributions of Humanitarian agencies among refugees and host communities in Handeni District, Tanzania. A sample of 420 respondents was taken for study using simple random and purposive sampling, while data was analyzed using the SPSS computer package. The findings considered the following as critical for resolution, promotion of dialogue between refugees and the host communities and change of perception and attitude towards refugees considered naturally violent. This has been reduced through peace campaigns by humanitarian agencies to ensure co-existence between refugees and host community. Issues on resource sharing, capacity building extension workers, ensuring basic services of equality as those available for host authority populations are provided to the refugees, developing a range of options with levels of self-help and related costs and loans relative to sanitation as they explore opportunities brought about by refugees.
\end{abstract}

Keywords: Refugee, humanitarian agencies, host communities, Tanzania 


\section{Introduction}

According to UNHCR (2007) to date, the country provides asylum to about 526,800 refugees. Majority of these refugees come from Burundi, Democratic Republic of Congo (DRC), Somalia and some few asylum seekers from Ethiopia, Uganda, Kenya and Zimbabwe. The Refugee Department in the Ministry of Home Affairs is mandated by the government to address all matters pertaining to refugees during their stay in the country. From a legal perspective, the Refugee Act No.9 of 1998 together with the National Refugee Policy forms the fundamental tools of addressing refugee issues (UNHCR, 2007).

The Act and the policy are complimented with other international refugee laws and conventions. The Ministry of Home Affairs in partnership with UNHCR collaborates with other government institutions and a number of other agencies ranging from local to international Non-Governmental Organizations in the implementation of the refugee assistance program in the country. Refugees are required by law to reside in special designated areas, either in refugee settlements or refugee camps (UNHCR, 2007).

The history of refugee management and administration in the country has over the years evolved through two different stages. Initially refugees were settled in large settlements where they were provided with farming land with a view of enabling them become self sufficient in food production within two to three years upon their arrival. These settlements were established largely in the seventies, there are three old refugee settlements which host Burundian refugees who entered in the country since 1960's which are Ulyankulu in Tabora region, Katumba and Mishamo in Rukwa region. Another settlement is Chogo which is in Handeni District in Tanga region. The Chogo settlement hosts refugees from Somalia (the Bantu - Somali refugees) who fled the civil war in Somalia since 1990 (UNHCR, 2007)

The Chogo village is situated almost $22 \mathrm{~km}$ from Handeni district. It was established in 2003 after Somali refugees from the Mkuyu camp moved to Chogo. The Somali are refugees who were running out of their country of origin from ethnic violence. REDESO under support from UNHCR has been running the village activities since March 2003. Ever since its establishment the refugees in this village have benefited from care and maintenance program provided by various UNHCR implementing partners and now REDESO, which took operation of the village in April 2003. Majority of the refugees in this village involve themselves in cultivation and some petty businesses within and nearby villages. However, for normal operation of the village UNHCR is monitoring and evaluating the progress of the village activities.

For normal provision of humanitarian assistance to the refugees, REDESO is running village activities using its technical departments, namely; General Settlement Management, Health, Environmental Management (Forestry), Health Sanitation, Community Development and Education. Other areas are water supply (non Agricultural) and Agriculture. UNHCR is also facilitating the local integration of 2,059 Somali refugees (as of $31 \mathrm{Dec} 2007$ ) living in the Chogo settlement in Tanga region, North of Dar es Salaam. The ancestors of many of these ethnic Bantu were taken to Somalia as slaves from present day Tanzania centuries ago. Based upon this historical link, the Government recognized these refugees on a group basis in the 
1990s and, in 2003, offered them the option to locally integrate and become Tanzanian citizens. UNHCR has been providing support to the integration and naturalization process. So far some 1,020 naturalization certificates have been issued by UNHCR (2007).

\section{Literature Review}

In 2007, there were 34 active conflicts in 25 locations throughout the world. In each case, innocent people were forced to flee from their homes. At the end of 2007, there were 14 million refugees in over 60 countries and more than 26 million internally displaced person's worldwide. According to the Office of the United Nations High Commissioner for Refugees (UNHCR), these numbers represent an increase for the second year in a row. The number of urban refugees is also a new and growing trend; half of all refugees now live in cities. 4 these statistics represent a global humanitarian crisis (UNHCR, 2007).

Since 1998, when it was founded, IRD has worked with refugees and the displaced through two different, but related types of programs: support to the displaced during displacement and support for reintegration when people return home or resettled permanently. IRD currently implements programs in Iraq, Jordan, Sudan, Chad, Cameroon, and Nepal. Programs in Mozambique, Indonesia, and Sri Lanka help IDPs who have been displaced by environmental disasters Chad is an example of the spillover effect sometimes created by large numbers of refugees seeking shelter across national borders. The local communities to which they flee are often struggling economically themselves. They can find themselves ignored as the international community focuses humanitarian assistance on the refugee population (IRD, August 2008).

In 2004, thousands of Darfurians began crossing into Chad, forming camps along its harsh eastern border. A severe drought coincided with the refugees' arrival, leading to water shortages, absence of pasture for livestock, and degradation of the environment. The Chadian host population, whose main assets are agriculture and livestock, felt a severe impact from the drought and the influx of refugees. IRD gives agricultural support to address these poor conditions through a range of programs, including training animal health agents, restocking small livestock in female-headed households, building rainwater harvesting structures to store water for livestock, and training members of butcher associations (IRD, 2004).

Local varieties of seeds are distributed for the planting season fruit and forest trees are planted for environmental protection. Villagers and refugees contribute their labor to build wells and ponds for irrigation and drinking water, and local committees are established to manage water usage. Despite the challenges presented by security and environmental issues, development activities are critical for encouraging self-reliance and for helping to prevent friction between the two populations (IRD, 2004).

IRD is working with a leading Nepali non-governmental organization (NGO), SAATHI, to give critically needed basic services and livelihood opportunities for IDPs, returned IDPs and conflict affected communities in western Nepal. To increase livelihood opportunities, IRD is providing vocational skills, business development training, helping with job placement, and raising awareness about micro-credit possibilities within the community. To improve drinking 
water supply, sanitation, and hygiene, IRD is constructing water systems in 12 villages. Key to any resettlement process is assuring that programs are transparent, and are conceived and implemented fairly in collaboration with the affected people and communities. In partnership with SAATHI, IRD is devoting significant effort and time to ensure that activities such as trainee and water point selection processes are participatory, free of conflict, and based on actual need (IRD, 2004).

There are close to 10,000 refugees in Ireland with rights similar to Irish nationals. Many are unable to return home and some may never do so. Many will make their permanent home in Ireland. Because of language barriers, unrecognized skills or qualifications and situations involving separated families, integration will not be easy for some refugees. This presents challenges and Ireland's statutory and voluntary agencies have been actively involved in assisting refugees and host communities to welcomes the emphasis that the Minister of State for Integration has given to the challenges surrounding the integration of recognized refugees in Ireland. UNHCR has advocated for special support for refugees at the initial phases of their integration and has welcomed the approach of Ireland to facilitate access by refugees to mainstream services. UNHCR carried out research on the needs of refugees in the area of integration in a study called Mapping Integration in April 2009 (UNHCR, 2009).

In our experience, local authorities and communities have played a key role in the successful first phases of integration of refugees and their children in Ireland, in particular those local initiatives that dealt with language barriers, access to health, education, employment and participation in sports and other local leisure activities. Although it can have different meanings and definitions, there are common features in the approach to the integration of urban refugees between UNHCR and the European Union and its Member States, like Ireland. UNHCR's policy in this area is continually developing in tandem with policies being defined and shaped European-wide and internationally (UNHCR, 2009).

Essentially, UNHCR sees integration as a two-way process involving efforts by the refugee and the host country to create the conditions that will allow individual refugees to start rebuilding their lives. In these efforts, it is the host country that must take the lead role and communicate its expectations for integration. UNHCR's definition of integration flows from the 1951 Refugee Convention and a number of the agency's Executive Committee's conclusions on durable solutions and local integration. Three key elements have been identified within integration, including the fact it involves legal challenges, questions around economic rights and self-reliance, and others concerning social and cultural integration. To ensure success, all three aspects must be supported by the host state (UNHCR, 2009).

The recommendations made by UNHCR on integration in the European context relate to ensuring that refugees and beneficiaries of subsidiary protection are included in integration programme that the special needs of refugees and beneficiaries of subsidiary protection are recognized in integration supports; that issues such as lack of documentation, potential trauma and the impact of the asylum process are addressed; that family reunification is facilitated in a timely manner and that there is access to a secure legal status as early as possible, with the potential for obtaining naturalization (UNHCR, 2009). 


\section{Macrothink}

Journal of Public Administration and Governance ISSN 2161-7104 2012, Vol. 2, No. 1

Funding pledges from governments to organizations such as UNHCR, other UN agencies and international NGOs should be honoured. In the meantime, groups like IRD will continue to give life 'saving humanitarian aid and assistance to help refugees regain their dignity and to prepare for their resettlement, whether it be inside or outside their home country From the mid-90s onwards, international humanitarian agencies such as EU, UNHCR and WFP invested heavily in the maintenance, rehabilitation and construction of roads, bridges and airstrips that were essential to the delivery of refugee services. The improved physical infrastructure and road network had a spill-over effect for host communities allowing for more trade, travel and services in these regions. Between 1995 and 1999, UNHCR spent close to USD 450,000 in road works alone, International assistance in the social services sector has been significant (UNHCR, 2009).

\section{Methodology}

\subsection{Study population}

Tanga region has a population of 1,642,015 people; Handeni district;248,633, Chogo village accommodates 420 people whereas Chogo refugee settlement hosts some 160 newly naturalized refugees who live and work together with Somali Bantu refugees around 160 and the neighboring communities 100 people. So this research comprised of Naturalized Somali Bantu refugees, Somali Bantu refugees, local people, and humanitarian agency members and resettlement officers.

Table 1 : POPULATION OF PEOPLE IN CHOGO VILLAGE

POPULATION NUMBER

PERCENTAGE

Somali Bantu refugees

160

$39 \%$

Naturalized Bantu refugees

160

$39 \%$

Host communities

100

$22 \%$

TOTAL 420 100

\section{Source: Researcher data, 2011}

\subsection{Sample Size}

While there are several ways of determining sample size including the rather abstract mathematical one, for simplicity/parsimony, the researcher decided to use the Slovenes formula in computing the sample size. The researcher used a sample size of 420 respondents. The respondents were stratified into one category; naturalized Somali Bantu refugees, local people, Somali Bantu refugees, resettlement officers and humanitarian agency. 


\section{Macrothink}

The researcher included 399 respondents of which 133 were naturalized Somali Bantu refugees, 118 Somali Bantu refugees and 133 were local people, 5 resettlement officers and 10 humanitarian agency members. This is because these respondents gave a clear picture and an equal representation of the feedback of the refugees and host community of chogo refugee settlement.

\section{Table 2 Sample Population of people in Chogo}

Respondent's

Naturalized Bantu Somali refugees

Somali Bantu Refugees

Host community

Resettlement officers

Humanitarian Agency

TOTAL
Number

$\%$
118

Source: Researcher data, 2011

\subsection{Data analysis}

Likert scales also called summated rating scales which are among the most commonly used in social research which looks at a number of statements both positive and negative but it asks for simple "agreement" or "disagreement" with the item, the respondent is provided with a range of possible responses. Thus, an appropriate scoring scheme which is associated with each of the five possible responses like strongly agree $=5$, Agree $=4$, Undecided $=3$, Disagree $=2$, strongly disagree $=1$ (R.Cauvery, 2003). Therefore the researcher used the above described method of scaling in order to save time and energy which contributed to the existing stock of knowledge in this area of research. 


\section{Findings}

\section{KEY}

Strongly agree

4.5-5

Agree

$3.5-4.4$

Undecided

Disagree

$1.5-2.4$

Strongly disagree

$0.5-1.4$

Table 3 showing descriptive Statistics for all the respondents

\begin{tabular}{lcccc}
\hline Contributions & $\begin{array}{c}\text { Mean for all } \\
\text { Respondents, }\end{array}$ & $\begin{array}{c}\text { Mean for } \\
\text { local people }\end{array}$ & $\begin{array}{c}\text { Mean for } \\
\text { Naturalized }\end{array}$ & $\begin{array}{c}\text { Mean for } \\
\text { Somali refugees }\end{array}$ \\
\hline Training Heath services & 3.2951 & 2.5574 & 3.7333 & 2.5000 \\
Shelter services & 3.6557 & 3.2951 & 3.0000 & 3.1667 \\
Forests planted by environment & 2.1967 & 2.6557 & 2.0667 & 3.1667 \\
Vocational training school & 3.8033 & 2.1967 & 4.4000 & 3.2222 \\
Rehabilitation of roads \& & 4.1475 & 3.8033 & 4.8667 & 3.5000 \\
Other infrastructure & & & & \\
Business training & 1.6885 & 4.1475 & 1.3333 & 3.2967 \\
Reintegration & 4.5028 & 4.2951 & 4.6667 & 4.5466 \\
\hline
\end{tabular}

\section{Source: Field data, 2011}

Humanitarian agencies were found playing a great role in helping the refuge settlement particularly Chogo refugee resettlement which was under study, the field results presented thus; rehabilitation of roads and other infrastructure schools with 4.1475, reintegration with 4.2951, vocational training schools with 3.8033 of the total sample. Added to the above is that the study found out that humanitarian agency has played a significant role in the reintegration process among the refugees and host community in Chogo village as evidenced by (4.2951).

This agrees with the literature that Humanitarian agencies like UNHCR and REDESO play a big a role curbing down the challenges among people's lives. It concurs with this study by UNHCR, 2009 .there are close to 10,000 refugees in Ireland with rights similar to Irish nationals. Many are unable to return home and some may never do so. Many will make their permanent home in Ireland. Because of language barriers, unrecognized skills or qualifications and situations involving separated families, integration will not be easy for 


\section{Macrothink}

some refugees. This presents challenges and Ireland's statutory and voluntary agencies have been actively involved in assisting refugees and host communities to welcomes the emphasis that the Minister of State for Integration has given to the challenges surrounding the integration of recognized refugees in Ireland. UNHCR has advocated for special support for refugees at the initial phases of their integration and has welcomed the approach of Ireland to facilitate access by refugees to mainstream services. UNHCR carried out research on the needs of refugees in the area of integration in a study called Mapping Integration in April 2009.

In our experience, local authorities and communities have played a key role in the successful first phases of integration of refugees and their children in Ireland, in particular those local initiatives that dealt with language barriers, access to health, education, employment and participation in sports and other local leisure activities. Although it can have different meanings and definitions, there are common features in the approach to the integration of urban refugees between UNHCR and the European Union and its Member States, like Ireland. UNHCR's policy in this area is continually developing in tandem with policies being defined and shaped European-wide and internationally (UNHCR, 2009).

Essentially, UNHCR sees integration as a two-way process involving efforts by the refugee and the host country to create the conditions that will allow individual refugees to start rebuilding their lives. In these efforts, it is the host country that must take the lead role and communicate its expectations for integration. UNHCR's definition of integration flows from the 1951 Refugee Convention and a number of the agency's Executive Committee's conclusions on durable solutions and local integration. Three key elements have been identified within integration, including the fact it involves legal challenges, questions around economic rights and self-reliance, and others concerning social and cultural integration. To ensure success, all three aspects must be supported by the host State (UNHCR, 2009). 
Table 4 showing Correlation contributions of humanitarian agencies among all respondents

\begin{tabular}{|c|c|c|c|c|c|c|c|c|}
\hline & contributions & Health & shelter & environment & school & road & Business & reintergration \\
\hline & 1000 & & & & & & & \\
\hline Health & .472 & 1.000 & & & & & & \\
\hline Shelter & .161 & .212 & 1.000 & & & & & \\
\hline Environment & .108 & -062 & .372 & 1.000 & & & & \\
\hline School & .140 & .071 & .242 & .147 & 1.000 & & & \\
\hline Road & .166 & .267 & .290 & .152 & .353 & 1.000 & & \\
\hline Business & -007 & .153 & .216 & .280 & -296 & .112 & 1.000 & \\
\hline Reintegration & .135 & .158 & .247 & .240 & .399 & .487 & .028 & 1.000 \\
\hline
\end{tabular}

\section{Source: Field data 2011}

From the correlation a analysis above with the correlation coefficients of $0.472,0.166,0.161$ of the total sample reported health services, rehabilitation of roads and other infrastructure, shelter services were the highest as shown in the table above. The respondents said that there are only two humanitarian Agencies that is; UNHCR, REDESO involved in providing the following services 
Regression Table 5 showing contributions of humanitarian agencies among all respondents

\begin{tabular}{|c|c|c|c|c|c|}
\hline & \multicolumn{2}{|c|}{$\begin{array}{l}\text { Unstandardized } \\
\text { Coefficients }\end{array}$} & \multicolumn{2}{|c|}{$\begin{array}{l}\text { Standardized } \\
\text { Coefficients }\end{array}$} & \multirow[b]{2}{*}{ Sig. } \\
\hline & B & Std. Error & Beta & $\mathrm{t}$ & \\
\hline (Constant) & .944 & .663 & & 1.423 & .161 \\
\hline Health $X_{1}$ & .392 & .101 & .494 & 3.877 & .000 \\
\hline Shelter $\mathrm{X}_{2}$ & .007 & .099 & .009 & .068 & .946 \\
\hline Environm $\mathrm{X}_{3}$ & .158 & .134 & .161 & 1.181 & .243 \\
\hline School $\mathrm{X}_{4}$ & .039 & .134 & .042 & .288 & .775 \\
\hline Road $X_{5}$ & .004 & .114 & .005 & .032 & .974 \\
\hline Business $\mathbf{X}_{6}$ & -.123 & .144 & -118 & -853 & .398 \\
\hline Reinterg $\mathrm{X}_{7}$ & .001 & .139 & .001 & .006 & .995 \\
\hline
\end{tabular}

A Dependent Variable: contributions Source: Field data 2011

$\mathrm{Y}=\mathrm{a}+\mathrm{bx}_{1}+\mathrm{cx}_{2}+\mathrm{dx}_{3}+\mathrm{ex}_{4}+\mathrm{fx}_{5}+\mathrm{gx}_{6}+\mathrm{hx}_{7}$

$\mathrm{Y}=0.944+0.392 \mathrm{x}_{1}+0.158 \mathrm{x}_{3}+0.039 \mathrm{x}_{4}+0.07 \mathrm{x}_{2}+0.004 \mathrm{x}_{5}+0.01 \mathrm{x}_{7}-123 \mathrm{x}_{6}$

From equation 2 the highest beta coefficient is $b$ Training health services at (0.392),dforests planted for Environment at 0.158 and e vocational Training schools at 0.039. and since the beta coefficient for business is negative shows that the humanitarian agencies have not been contributing anything concerning business training to both refugees and the host community.

\subsection{Health services}

More so, it was found out by the study that humanitarian agencies have provided medical facilities and food to both the local people and the refugees. It was revealed by the study that with establishment of the Chogo refugee settlement, medical facilities have been extended nearer because the local people use the available medical facilities that were set up for the refugees which has improved their health standards. In addition, food is provided to some residents in the host communities, however, it was noted that this was not common in the community. This implies humanitarian agencies have played a great role in trying to bring harmony among the host community and the refugees in Chogo refugee settlement. Added to 
the above it was revealed by the study by some respondents from the REDESO Department have provided counseling to the conflicting parties which has led to round table talks and teaching them better ways of living together which they said it is done through workshops and seminars, this has reduced the occurrence of the conflicts between the refugees and the host community.

\subsection{Shelter services}

The study found out that humanitarian agency has played a significant role in providing shelter as evidenced by (472). Above findings concurs with UNHCR (2004) Humanitarian agencies like UNHCR provide shelter and rehabilitate people's lives. It was found that the Humanitarian agencies take the basics of life as a priority hence provides food and shelter to the refugees this has restored the hopes of the refugees. On the other hand the need to recognize the universality of recipient rights while Humanitarian agencies simultaneously taking deeper look at the individual's situation, treating individuals as responsible actors and creating a legitimate space for the refugees and displaces in the decision making process.

More so, this study concurs with study in Sudan (2004) where thousands of Darfurians began crossing into Chad, forming camps along its harsh eastern border. A severe drought coincided with the refugees' arrival, leading to water shortages, absence of pasture for livestock, and degradation of the environment. The Chadian host population, whose main assets are agriculture and livestock, felt a severe impact from the drought and the influx of refugees. IRD gives agricultural support to address these poor conditions through a range of programs, including training animal health agents, restocking small livestock in female-headed households, building rainwater harvesting structures to store water for livestock, and training members of butcher associations (IRD, 2004).

Local varieties of seeds are distributed for the planting season fruit and forest trees are planted for environmental protection. Villagers and refugees contribute their labor to build wells and ponds for irrigation and drinking water, and local committees are established to manage water usage. Despite the challenges presented by security and environmental issues, development activities are critical for encouraging self-reliance and for helping to prevent friction between the two populations (IRD, 2004)

\subsection{Rehabilitation of roads and other infrastructure services}

With humanitarian agencies like UNHCR in place; education facilities have been extended to the refugees and the host community as shown by (0.140). This concurs with this study in Nepal that those humanitarian agencies such as IRD working with Nepali non-governmental organization (NGO), SAATHI, gives needed basic services and livelihood opportunities for returned IDPs and conflict affected communities in western Nepal. To increase livelihood opportunities, IRD is providing vocational skills, business development training, helping with job placement, and raising awareness about micro-credit possibilities within the community. To improve drinking water supply, sanitation, and hygiene, IRD is constructing roads and water systems in 12 villages. Key to any resettlement process is assuring that programs are transparent, and are conceived and implemented fairly in collaboration with the affected 
people and communities. In partnership with SAATHI, IRD is devoting significant effort and time to ensure that activities such as trainee and water point selection processes are participatory, free of conflict, and based on actual need (IRD, 2004).

More so, many other opportunities have been provided by these humanitarian agencies for example the reintegration process of refugees into host communities which concurs with the above findings in Table above and concurs with this study according European council and exiles a net work for European refugees and assisting non-governmental organizations. In the last thirty years the international community has experienced many attempts, some successful and others less so as to move to peace and justice leading to conflict transformation which can be done through the notion of "reintegration" that usually answer the concerns by allowing individuals to return to their communities and be accepted as valued participants in the life of those communities (ECRE, 2005)..

While it is widely acknowledged that the successful integration of refugees in European countries is to benefit all (refugees, host communities, governments, economies, etc), the distinct climate of intolerance and racism in Europe is having a negative impact on the integration process of refugees. What is clear is that where refugees are marginalized through negative media reporting, political antipathy, insecure legal status, a lack of educational and employment opportunities, and/or hostility from local communities there is less integration. Those who feel threatened or excluded from the host society, instead of striving to belong, may seek to emphasize their difference through isolating themselves in their own communities and may also be more open to

Radical influences. What is also clear is that some policies of European states undermine integration, while many policies in place to promote it are not being effectively implemented. Due to the forced nature of their migration and their experiences, compared with other migrant groups, refugees will often have specific needs that have to be met in order to support their integration. They will often be one of the most vulnerable groups in society while also being the most resilient. It is therefore important they are being helped by these non-governmental organizations to gear the integration refugees and the displaced into host communities. (ECRE, 2005).

The debate in Europe often places the onus on the responsibilities of refugees to integrate them. ECRE and its member agencies stress the need to approach the integration of refugees as a dynamic two-way process which begins from the day a refugee arrives within the new host society. We consider it a continuous long term process enabling refugees and their communities to live in harmony with the host population of which they form a part. Refugee integration therefore places demands both on receiving societies and on the individuals and communities concerned (ECRE, 2005).

\section{Conclusions}

Humanitarian agencies like UNHCR and REDESO have played a big a role in curbing down the challenges among people's lives like many refugees have been unable to return home and some may never do so because of language barriers, unrecognized skills or qualifications and 
situations involving separated families, integration has always not been easy for some refugee in Chogo refugee settlement. Therefore voluntary agencies have been actively involved in assisting refugees and host communities.

More so, agencies have played a significant role in providing shelter whereby UNHCR has been providing shelter to rehabilitate people's lives in Chogo refugee settlement. It was found that the Humanitarian agencies take the basics of life as a priority hence provides food and shelter such iron sheets to the refugees and this has restored the hopes of the refugees in the resettlement. On the other hand the need to recognize the universality of recipient rights while Humanitarian agencies simultaneously taking deeper look at the individual's situation , treating individuals as responsible actors and creating a legitimate space for the refugees in the decision making process. Despite the challenges presented by security and environmental issues, development activities brought by REDESO and the UNHCR are critical for encouraging self-reliance and for helping to prevent friction between the two populations.

\section{Recommendations}

It was evident that the Tanzania government allocates land only to every refugee who has acquired Tanzanian citizenship without considering other refugees priorities like peace campaigns among refugees and the host community, formation of common committees and hosting meetings and other developmental activities. Humanitarian agencies like UNHCR have always tried to avail these naturalized refugees with iron sheets where other things like water, medical care should be taken care of by the government and any donation from these humanitarian services should always target both refugees and the host community. Tanzanian government should access the life of naturalized refugees after the departure of the humanitarian agencies.

\section{References}

Akinboye, S.O. and Ottoh, .F.O. (2005). A Systematic Approach to International Relations. Lagos: Concept Publications.

Brock.G.\& Brighouse .H.(2005). the political philosophy of cosmopolitanism.London: Cambridge University Press.

Betts. A. (2004). "International Cooperation and the Targeting of Development Assistance for Refugee Solutions: Lessons from the 1980's". New Issues in Refugee Research: Working Paper n. 107 (September).

Betts. A. (2005). "International Cooperation between North and South to Enhance Refugee Protection in Regions of Origin". RSC, Working Paper n. 25 (July).

Baker J. (1995). “Refugee and Labour Movements in Sub-Saharan Africa: A review”. Studies on Emergencies and Disaster Relief.

Mugenda,A. \& Mugenda, O. (2003). Research methods; Quantitative and qualitative Approaches. Nairobi: Acts press.

Saleyhan I. (2003). "Refugees and the Spread of Civil War". 


\section{Macrothink}

Journal of Public Administration and Governance ISSN 2161-7104 2012, Vol. 2, No. 1

Samson S. W, (2007) Traditional Mechanisms of Conflict Resolution in Southern Sudan Workshop on "Resources, Governance Structures, and Civil War," Joint Sessions of Workshops of the European Consortium for Political Research, Uppsala, Sweden, 13-18 April, and the 100th Annual Meeting of the American Political Science Association, Chicago, IL, USA, 2-5 September

United Nations High Commissioner for Refugees (UNHCR), (2007, 2004\&2009 ) Global Trends: Refugees, Asylum-seekers, Returnees, Internally Displaced and Stateless Persons," June.

UNHCR, (2002\&2003) New issues in refuge research, No 57 Geneva evaluation and policy analysis unit, responding to protracted refugee situations: a case study Liberian refuge in Ghana - Geneva Evaluation and policy analysis in it, UNHCR (2004\&2005). "Map. Ethnicity of Sudanese Refugees in Eastern Chad”. Geneva: Switzerland.

UNHCR, (2004) Global Refugee Trends. Geneva, Switzerland :UNHCR.

Women's Commission for Refugee Women and Children (2005). Don't Ever Forget Us: the Education and Gender-based Violence Protection Needs of Adolescent Girls from Darfur in Chad. New York. 